\title{
LANGUAGE FUNCTION ACQUISITION OF THREE-YEAR-OLD CHILDREN IN URBAN EDUCATED FAMILY ENVIRONMENT
}

\author{
Anita Dewi Kurniasari ${ }^{1}$, Yakub Nasucha ${ }^{2}$, Ali Imron Al-Ma'Ruf ${ }^{3}$ \\ ${ }^{1}$ Student of Indonesian Language Education Master's Program \\ ${ }^{2,3}$ Lecturer of Indonesian Language Education Master's Program \\ Faculty of Teaching and Education \\ Universitas Muhammadiyah Surakarta \\ Ahmad Yani Street 1, Kartasura, Surakarta, Indonesia
}

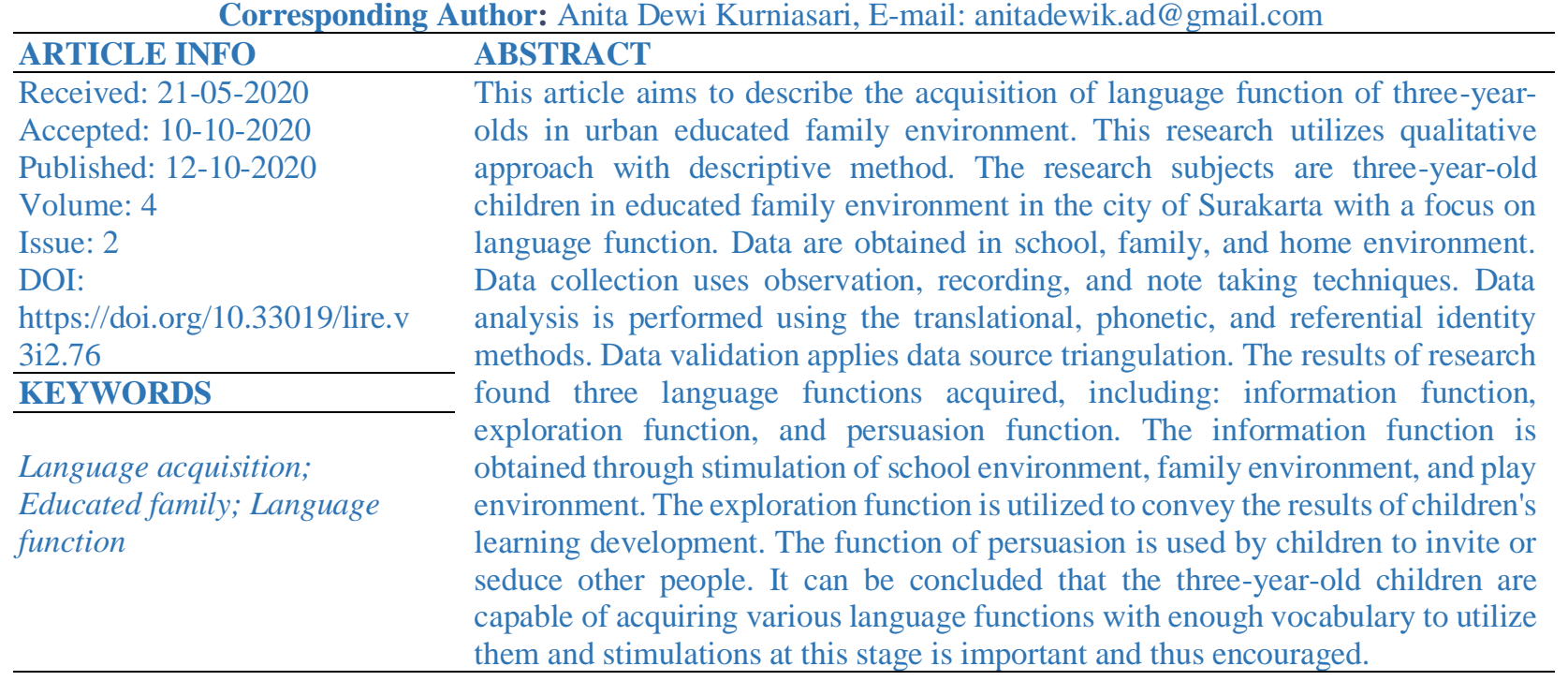

\section{INTRODUCTION}

Acquisition of first language is very important for a child because it will determine the mastery of the second language and subsequent languages (Suntini \& Ajat, 2018:190). In addition, according to Natsir (2017:21), language acquisition is a very amazing thing especially in the process of acquiring the first language that by a child without any special learning. Abdurrahman, et al., (2019:138) explains the development of children's language is the child's ability to respond to sounds, follow commands, and speak politely.

Language development in early childhood is very important because with language as a basic ability, children will be able to improve their other abilities (Gani, et al., 2017:151); which attest to the importance of conducting this research.

This is in accordance with what was stated by Saputri (2018:210) that the acquisition of children's language or commonly referred to as language acquisition shows that there is a potential that can be measured in the human brain, especially children. 
The reason for choosing the scope as three-year-old child in an urban-educated environment is because at that age children begin to show their personality traits and characteristics. As stated by Khairi (2018:16), early childhood is a different span of individuality, unique and has its own characteristics according to the stage of the age.

The acquisition of children's language always experiences development. Every child has the ability to speak with their own uniqueness. Children also have the ability to understand and express their language according to what they digest. In this case, language acquisition in children will bring children to the fluency of speaking (Sebayang, 2018:106).

Children aged three years have a more sensitive ability to absorb things and have memories that tend to be more responsive compared to ages above the toddler so that at these ages children should get good language acquisition. Children can express language by using various methods such as dialogue, asking questions and answering questions. The family environment is an arena where the personality traits of children are formed, so the family is the first education avenue for children (Setiawan, et al., 2017:113).

Research on language acquisition of three-year-old children in urban educated environment will investigate the forms and functions of children's language acquisition. Arsanti (2014:25) states that acquisition means the process of language acquisition done by the child naturally when they learn their native language. How is the language acquisition of three-year-old children in urban educated family environment and what are the language functions involved? This article will answer that question.

\section{LITERATURE REVIEW}

In previous studies, Simanjuntak (2017) focuses on children's language with speech analysis that shows the types of words, verbs, adjectives, and adverbs. Sebayang (2018) studies language acquisition in terms of phonology where the child was able to pronounce certain sounds. Wulandari (2018) studies the acquisition of affixation in terms of phonology, morphology, syntaxis, and semantics. Sobari, et al. (2018) examines the acquisition of language studied by phonology, where the object has several processes, namely the distribution process of syllable structures and the process of assimilation. Crowe \& Sharynne (2018) investigates children's speech mastery which involves the perception and production of consonants, vowels, consonant groups, tones, prosidiic features, and phonological rules of the language they used with the results of speech being understood.

Research of Syarif, et al. (2017) focuses on the type of student perception of parenting; student perception of parenting has a direct and significant influence on student learning outcomes. The level of parental education has a direct and significant influence on student learning outcomes. Arciuli \& Evan (2016) examines the differences in individuals in learning (SL), who have been

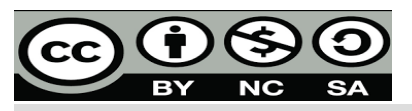

This work is licensed under Creative Commons Attribution-ShareAlike 4.0 Internasional. Copyright @ 9 2020, Anita Dewi Kurniasari, Yakub Nasucha, \& Ali Imron Al-Ma’Ruf 
involved in language acquisition, independently predicting syntactical understanding of children aged 6-8 years.

This study discusses the acquisition of language functions of three-year-old children in urban educated environment including: Information function, exploration function, and persuasion function (Chaer, 2015).

\section{METHODOLOGY}

\subsection{Data}

In accordance with the data source above, the data collection in this study uses the method of observation, recording technique, and note taking technique. The method of observation is done by listening to the recorded conversations of children obtained from the school environment, family environment, and the home environment. Recording technique is used to obtain data in the form of sound sourced from recorded conversations of informants (Sudaryanto, 2015:25). Furthermore, after a number of research data are obtained, data is recorded on the data card according to the type of data.

Data analysis is performed using the translational identity method, the phonetic identity method, and the referential identity method. In addition, the constituent analysis method is utilized with a number of techniques, namely techniques of expansion, deletion, merging, replacing, insertion, and paraphrasing. Data validation uses data source triangulation. Data presentation technique is done by informal presentation.

\subsection{Method}

Descriptive qualitative research in this study is used to describe the acquisition of language functions of three-year-old children in urban-educated environments in the form of classifying language functions, including: information, exploration, and persuasion functions.

\section{RESULTS AND DISCUSSION}

The results and discussion of this study are focused on the language function acquisition of threeyear-old children in urban educated environments including the information function, the exploration function, and the persuasion function (Chaer, 2015).

\subsection{Result}

\section{Acquisition of Language Function of Three-Year-Old Children in Urban Educated Environments}

The results of acquisition of language function of three-year-old children in urban educated environments in Surakarta are presented in table form as follows: 


\section{Table1: Information Function}

\begin{tabular}{clll}
\hline No. & Child Identity & Informational Sentence & \multicolumn{2}{c}{ Sentence Variation } \\
\hline 1. & Raiyhan & Ini ada iannya & $\begin{array}{l}\text { Ini (Subject) ada iannya } \\
\text { (Predicate) }\end{array}$ \\
2. Fatah & $\begin{array}{l}\text { Fatah dah akpung } \\
\text { (mandi) }\end{array}$ & Fatah (S) dah akpung (P) \\
3. Naufal & Aku mau uat mobi mobi & $\begin{array}{l}\text { Aku (S) mau uat (P) mobi } \\
\text { mobi (O) }\end{array}$ \\
\hline
\end{tabular}

Table 2: Eksploration Function

\begin{tabular}{llll}
\hline No. & Child Identity & Eksploration Sentence & \multicolumn{1}{c}{ Sentence Variation } \\
\hline 1. & Riski & $\begin{array}{l}\text { Iski udah isa hitung } \\
\text { anga-angka }\end{array}$ & $\begin{array}{l}\text { Iski }(\mathrm{S}) \text { udah isa itung }(\mathrm{P}) \\
\text { anga-angka }(\mathrm{O})\end{array}$ \\
2. Ardhen & $\begin{array}{l}\text { Aku ukha ambar } \\
\text { bulhat-ulhat, bilang } \\
\text { bitang }\end{array}$ & $\begin{array}{l}\text { Aku }(\mathrm{S}) \text { ukha ambar }(\mathrm{P}) \\
\text { bulhat-ulhat, bilang bitang } \\
\text { (O) }\end{array}$ \\
\hline
\end{tabular}

Table 3:Persuasion Function

\begin{tabular}{llll}
\hline No. & Child Identity & \multicolumn{1}{c}{ Sentence } & \multicolumn{2}{c}{ Sentence Variation } \\
\hline 1. & Dika & $\begin{array}{l}\text { Atu belum andhi nggu } \\
\text { amah ulang }\end{array}$ & $\begin{array}{l}\text { Atu }(\mathrm{S}) \text { belum andhi } \\
\text { nggu amah ulang (K) }\end{array}$ \\
\hline
\end{tabular}

Children's language functions in tables 1,2, and 3 above can be analyzed as follows:

\section{Information Function}

The information function is in the form of declarative and interrogative sentences which serve to convey messages or mandates. This is in line with what is conveyed by Sudaryanto \& Mukhammad (2020:44) that the information function is to convey an explanation or information to the listener and reader. The following is the acquisition of information functions for three-year-old children in educated environment in Surakarta City:

a. News sentence functioning as information

The news sentence in this analysis has an information function. Suliani, et al (2013:5) states that news sentences are generally used by speakers to convey an event to others. The news 
delivered to other people has an information function. The following is analysis of the news sentence as a function of information:

$$
\begin{array}{ll}
\text { Utterance } & \text { : ini ada iannya } \\
\text { Meaning } & \text { : Ini ada ikannya (there is fish here) } \\
\text { Speaker } & : \text { R (Raiyhan) to A (Azka) }(18 / 02 / 2020)
\end{array}
$$

Data (1) is a news sentence used to convey information to others (Gunawan, 2013:12). News sentence that has information function are shown in the R phrase "Ini ada iannya ", the news sentence has the grammar structure of the subject (ini), the predicate ( $a d a)$, and the object (ian). The sentence emphasizes the predicate and object. R's utterance serves to provide information to A by showing the presence of fish that he has seen.

A was happy because he had been told by $\mathrm{R}$ that there was a fish pond in his school yard. $\mathrm{R}$ and $\mathrm{A}$ then told other friends to come together to see the fish in their school yard. The message that $\mathrm{R}$ says to A serves as information in conveying news factually. The utterance took place during recess.

$\begin{array}{cl}\text { (2) Utterance } & : \text { Fatah dah akpung } \\ \text { Meaning } & : \text { Fatah sudah mandi (Fatah has bathed) } \\ \text { Speaker } & : \text { F (Fatah) to M (Mama) (7/09/2019) }\end{array}$

Data (2) is a news sentence; this sentence is used to express news for others to know, (Hasibuan, 2020:20). The news sentence serves to convey information " $F$ sudah mandi", to inform $\mathrm{M}$ that $\mathrm{F}$ has taken a bath. $\mathrm{F}$ gave information to $\mathrm{M}$ according to what has been done by F. The utterance took place on the terrace of the house, in the afternoon when $\mathrm{M}$ came home from work.

In the utterance, F can convey information using declarative sentences that function to convey a message in accordance with what $\mathrm{F}$ has done.

(3) Utterance : aku mau uat mobi mobi

Meaning : aku akan membuat mobil-mobilan (I will make toy car)

Speaker : N (Naufal) to R (Riffat) (18/02/2020)

Data (3) contains information function where N stated "aku mau uat mobi-mobi" in the form of news sentence. Structure wise, the sentence is formed from subject (aku), predicate (mau uat), and object (mobi-mobi). The sentence is used to inform $\mathrm{R}$ that $\mathrm{N}$ will form the blocks into a toy car. $\mathrm{N}$ is able to deliver news sentences as a function of information. The sentence spoken by $\mathrm{N}$ has a less clear vocabulary, but the meaning spoken by $\mathrm{N}$ can convey information. The utterance took place in the playroom during the day. 


\section{Exploration function}

Exploration function in found in the form of news sentence that has explorative nature. The exploration function in this analysis is to convey something new. In line with what is stated by Prasetiawan, (2017:79), that the exploration function is used to explain things, cases, and circumstances.

a. News sentence functioning as exploration

News sentence is a sentence that conveys important information from a news story (Purwitasari, et al., 2015). The information conveyed is used as an exploratory function to convey a matter of learning exploration as well as exploration to explain the situation.

(4) Utterance : iski udah isa hitung, anga-angka

Meaning : Riski sudah bisa hitung angka-angka

Speaker : : R (Riski) to I (Ibu) (15/12/2019).

Data (4) shows a news sentence, which is used to preach, declare, or describe a matter, such as events (Panjaitan \& Ipan, 2019:291); shown in utterance "iski udah isa hitung, anga-angka" (Riski has been able to count numbers). Structure wise, it contains subject (iski), predicate (udah isa hitung), and object (angka-angka). The news sentence serves to explain the progress of learning of $\mathrm{R}$ to $\mathrm{I}$, who previously could only count numbers from one to six, and now has a development of up to the number ten. The learning progress that $\mathrm{R}$ said has an exploratory function. The utterance took place at night in the living room.

(5) Utterance : aku ukha ambar bulhat-bulhat, bilang bitang

Meaning : Aku suka gambar bulat-bulat, bintang-bintang

Speaker : A (Ardhen) to T (Tika) (18/02/2020)

Data (5) has a language function of exploration, shown in utterance "aku ukha ambar bulhat-bulhat, bilang bitang" (I like to draw circles, stars). Structurally, A has been able to speak utterance completely, which includes subject ( $a k u$ ), predicate ( $u k h a$ ambar), and object (bulhat-bulhat, bilang-bitang). A tells $\mathrm{T}$ the results of his drawing, that $\mathrm{A}$ is drawing "round, stars" and tells $\mathrm{T}$ that A likes the activity. The above sentence has the function of exploratory language to convey his pleasure in drawing, A who previously only enjoyed playing now has progressed to explore. The utterance took place in the living room in the afternoon.

\section{Persuasion Function}

The function of persuasion is a function used to persuade, seduce, or move someone to do something (Musaffak, 2015:231). The persuasion function in the acquisition of language is found in the form of news sentences used to seduce, and question sentences that function to persuade. Utterance of command sentence with persuasion function is used to move a person to do something that the speaker wants. The following is analysis of the persuasion function: 


\section{a. News sentence functioning as persuasion}

The news sentence is a sentence to convey information factually or according to the experience of the speaker (Usman, 2015:23). The news sentence functions as a persuasion that is used to influence or seduce the other person to do what the speaker wants.
(6) Utterane
: Atu belum andhi nggu amah ulang
Meaning
: Aku belum mandi menunggu mama pulang
Speaker
: D (Dika), K (Kakak), and M (Mama) (17/12/2019)

Data (6) shows a news sentence that is used to express something (Nirmala \& Marissa, 2020:32); news sentence stated by D have a persuasive language function. Utterance "Atu belum andhi nggu amah ulang" (I have not bathed, waiting mama come home) is structured by subject (atu), predicate (belum andhi), adverb (nggu amah ulang). The utterance contains persuasion function where $\mathrm{D}$ seduces $\mathrm{K}$ so as not to take a bath. K tells $\mathrm{D}$ to take a shower before $\mathrm{M}$ comes home, but $\mathrm{D}$ refuses because $\mathrm{D}$ wants to be bathed by $\mathrm{M}$. The utterance took place in D's room in the afternoon.

\subsection{Discussion}

The findings of the acquisition of children's language function in this study differ from the research conducted by Asri \& Indah (2019); Budiana (2020) Asri's research focuses on the phonological aspects that are influenced by the family environment, which results of research show one-yearold children have good language development and are able to say nouns, work, and nature. Research on language acquisition by Budiana shows that the language of children aged two and a half to three years is increasing. Nouns and verbs also increase due to language repetition received.

Based on the results of the study, the language functions of three-year-old children in urbaneducated family environments are grouped into three language functions. 1) Information function, used by children to deliver a story to others. 2) The function of exploration, in addition to being able to deliver news, children are able to convey something new. This shows an increase in learning development. The function of persuasion, children are able to express information that contains an invitation and even able to influence others.

Practically, this can be used by parents or teachers as a basis for stimulating children in order to improve learning. Parents can stimulate children with questions or tell what is done at home. At school, teachers can apply learning techniques using media that can stimulate children's speaking abilities.

\section{CONCLUSION}

Acquisition of language functions in three-year-old children involves three language functions: a) Information functions, obtained through environmental stimuli which include: school 
environment, family environment, and play environment. So, the development of children's language function is very dependent on what the child receives from outside. b) The function of exploration, used to convey learning exploration, which is to convey a situation or something new. c) The function of persuasion, used by children to invite, influence, or get someone to do something.

In term of language development, children aged three years already have a vocabulary with sufficient numbers. With the vocabulary they have and the language functions they have acquired, they are able to express the intentions. The utterances expressed are no longer in the form of oneword and two-word utterances. But they are able to make phrases and short sentences that are structurally sound, and utterances spoken in it contain elements of the subject, predicate, object, and various information. They are able to understand the question and answer the question correctly, able to remember the surrounding environment and also express their feelings.

Given the rapid acquisition of language in three-year-old children, and being highly dependent on the environment, it is necessary for them to be given stimulation in the form of storytelling, singing, playing that uses dialogue (role playing). Thus, children can learn vocabulary and language functions in order to improve their fluency.

\section{ACKNOWLEDGEMENT}

Thank you to Ministry of Higher Education, Technology, and Research for funding this research. 


\section{REFERENCES}

(1) Abdurrahman, et al. (2019). Pemerolehan Bahasa pada Anak Usia 3 Tahun. Jurnal Obsesi, 3(1), 137-145. Retrieved From https://obsesi.or.id/index.php/obsesi/article/view/156

(2) Arciuli \& Evan. (2016). Individual Differences in Statistical Learning Predict Children's Comprehension of Syntax Evan. Child Development, 87(1), 184-193. Retrieved From https://doi.org/10.1111/cdev.12461

(3) Arsanti.M. (2014). Pemerolehan Bahsa pada Anak (Kajian Psikolinguistik). Jurnal PBSI, 3(2), 24-47. Retrieved From http://research.unissula.ac.id/file/publikasi/211315023/3959

(4) Asri \& Indah. (2019). Pemerolehan Bahasa Pertama pada Anak Usia Dini. Jurnal Obsesi : Jurnal Pendidikan Anak Usia Dini, 3(1), 265-273. Retrieved From https://doi.org/10.31004/obsesi.v3i1.160

(5) Budiana. N. (2020). Pemerolehan Bahasa Anak Usia 2,5 Tahun Tataran FonologiMorfologi dan Sintaksis. Jurnal Ilmiah Semantika, 1(2), 35-41. Retrieved From https://doi.org/http://jurnal.umus.ac.id/index.php/semantika/article/view/169

(6) Chaer, A. (2015). Psikolinguistik:Kajian Teoritik. Bandung: Rineka Cipta.

(7) Crowe \& Sharynne. (2018). Children's Consonant Acquisition in 27 Languages: A CrossLinguistic Review. Journal of Speech-Language Pathology, 1(2), 1-26. Retrieved From https://doi.org/https://pubs.asha.org/doi/abs/10.1044/2018_ajslp-17-0100

(8) Gani, et al. (2019). ) Memahami Bahasa Anak Usia 14 Bulan Melalui Unsur "NonLinguistik." Jurnal Obsesi, 3(1), 146-152. Retrieved From https://doi.org/10.31004/obsesi.v3i1.155

(9) Gunawan.F. (2013). Wujud Kesantunan Berbahasa Mahasiswa terhadap Dosen di STAIN Kendari: Kajian Sosiopragmatik. Jurnal Arbitrer, 1(1), 8-18. Retrieved From http://arbitrer.fib.unand.ac.id/index.php/arbitrer/article/view/2/2p

(10) Hasibuan.H. (2020). Hubungan Penguasaan Fungsi Kalimat dengan Kemampuan Menulis Karangan pada Siswa Kelas VIII SMP Negeri 2 Sosa. Jurnal Sinar Edukasi, 01(01), 1624. Retrieved From http://iitss.or.id/index.php/jse/article/download/13/10

(11)Khairi.H. (2018). Karakteristik Perkembangan Anak. Jurnal Warna, 2(2), 15-28. Retrieved From http://ejournal.iaiig.ac.id/index.php/warna/article/view/87/91

(12) Musaffak. (2015). Analisis Iklan Makanan dan Minuman pada Telivisi Berdasarkan Struktur dan Fungsi Bahasa. Jurnal Kembara, 1(2), 224-232. Retrieved From /http://202.52.52.22/index.php/kembara/article/download/2618/3269

(13) Natsir.N. (2017). Hubungan Psikolinguistik dalam pemerolehan dan Pembelajaran Bahasa. Jurnal Retorika, 10(1), 20-29.

Retrieved From http://ojs.unm.ac.id/retorika/article/view/4610

(14)Nirmala \& Marisssa. (2020). Tindak Tutur dalam Upacara Etnis Tionghoa Peranakan. Jurnal Pendidikan Bahasa Dan Sastra, 13(1), 31-43. Retrieved From journal.um- 
surabaya.ac.id/index.php/Stilistika/article/viewFile/3710/2547

(15) Panjaitan \& Ipan. (2019). Kemampuan Menentukan Fungsi Sintaksis dalam Kalimat Tunggal oleh Siswa Kelas VI SD. Jurnal Tapanuli, 1(2), 290-295. Retrieved From http://ojs.unm.ac.id/retorika/article/view/4610http://journal.ojsunita.com/index.php/unita/article/download/41/39

(16) Prasetiawan.D. (2017). Pemerolehan Bahasa pada Anak Suku Sasak dalam Perspektif Psikolinguistik. Jurnal Pendidikan Dan Sastra, 17(1), 72-80. Retrieved From http://ojs.unm.ac.id/retorika/article/view/4610https://media.neliti.con/media/publications/ 118961-ID-pemerolehan-bahasa-pada-anak-suku-sasak.pdf

(17) Purwitasari, et al. (2015). Pembobotan Kalimat Berdasarkan Fitur Berita dan Trending Issue untuk Peringkasan Multi Dokumen Berita. Jurnal Ilmiah Teknologi Informasi, 13(1), 38-44. Retrieved From http://eprints.umm.ac.id/36591/2

(18)Saputri. R. (2018). Pemerolehan Bahasa Anak Usia 3 Tahun. Jurnal Linguistik, 2(4), 210214. Retrieved From http://ojs.unm.ac.id/retorika/article/view/4610http://ejournal.unwmataram.ac.id/trendi/arti cle/view/62

(19) Sebayang, H. K. S. (2018). Analisis Pemerolehan Bahasa Pertama (Bahasa Melayu) pada Anak Usia 3 Tahun. Jurnal Pena Indonesia, 4(1), 106-114. Retrieved From http://ojs.unm.ac.id/retorika/article/view/4610https://journal.unesa.ac.id/index.php/jpi/arti cle/view/2313

(20) Setiawan, et al. (2017). Pengaruh Lingkungan Keluarga terhadap Minat Belajar Anak. Jurnal Paedagogie, V(2), 111-119.

Retrieved From http://e-jurnal.stkipmsampit.ac.id/index.php/Pendidikan/article/view/61

(21) Simanjuntak, M. (2017). Pemerolehan Bahasa Anak (Kajian Mean Length of Utterence 'MLU') Luzca Fortunata Roito Situmorang (Anak Usia Satu Tahun Sebelas Bulan). Jurnal Bahasa, 1(2), 1-11. Retrieved From https://jurnal.unimed.ac.id/2012/index.php/kultura/article

(22) Sobari, et al. (2018). Pemerolehan Bahasa Anak Usia 2 -3 Tahun Ditinjau dari aspek Fonologi. Jurnal Pendidikan Bahasa Dan Sastra Indonesia, 1(4), 591-602. Retrieved From http://ojs.unm.ac.id/retorika/article/view/4610

(23) Sudaryanto. (2015). Metode dan Aneka Teknik Analisis Bahasa: Pengantar Penelitian Wahana Kebudayaan secara Linguistis. Yogyakarta: Sanata Dharma University Press.

(24) Sudaryanto \& Mukhammad. (2020). Kajian Bentuk dan Fungsi Jargon di Grup Facebook dan Kaitannya dengan Pembelajaran Teks Negosiasi. Jurnal Pendidikan Bahasa Dan Sastra Indonesia, 3(1), 35-48.

\section{(c) (i) 8 (9)}

This work is licensed under Creative Commons Attribution-ShareAlike 4.0 Internasional. Copyright $@$ @ 2020, Anita Dewi Kurniasari, Yakub Nasucha, \& Ali Imron Al-Ma’Ruf 
Retrieved From http://ojs.unm.ac.id/retorika/article/view/4610

(25) Suliani, et al. (2013). Pemerolehan Kalimat Anak di Paud Babul'Ilmi dan Implikasinya terhadap Pembelajaran PAUD. Jurnal Kata, 1(7), 1-12. Retrieved From http://ojs.unm.ac.id/retorika/article/view/4610http://jurnal.fkip.unila.ac.id/index.php/BIN doi/article/view/2972

(26) Suntini \& Ajat. (2018). Analisis Pemerolehan Bahasa Pertama pada Anak Usia Satu Tahun sampai Usia Lima Tahun di Kelurahan Cigintung. Jurnal Pendidikan Bahasa Dan Sastra Indonesia, 13(2), 190-198. Retrieved From https://journal.uniku.ac.id/index.php/FON/article/view/1561/1151

(27) Syarif, et al. (2017). Pengaruh Persepsi Siswa terhadap Pola Asuh Orang Tua dan Tingkat Pendidikan Orang Tua terhadap Motivasi dan Hasil Belajar Biologi Siswa Kelas X dan XI IPA SMAN 8 Makassar Tahun Ajaran 2017/2018. Prosiding Seminar Nasional, 4(1), 98107. Retrieved From http://journal.uncp.ac.id/index.php/proceding/article/view/1208

(28) Usman, H. (2015). Studi Pemerolehan Bahasa pada Anak Usia 4 Tahun (Kajian Sintaksis ). Jurnal Linguistik Terapan, 5(2), 16-27. Retrieved From http://jlt.polinema.ac.id/index.php/jlt/article

(29) Wulandari, I. D. (2018). Pemerolehan Bahasa Indonesia Anak Usia 3-5 Tahun di PAUD Lestari Desa Blimbing Kecamatan Pacitan Kabupaten Lamongan. Jurnal Lingua, 6(1), 7483. Retrieved From http://ojs.unm.ac.id/retorika/article/view/4610http://journal.umsurabaya.ac.id/index.php/lingua/article/view/1346 